\title{
Analisis Isi Kekerasan Verbal dalam Sinetron “Tukang Bubur Naik Haji The Series" di RCTI (Analisis Isi Episode 396 - 407)
}

\author{
Alvionita Choirun Nisa dan Umaimah Wahid \\ Fakultas Ilmu Komunikasi Universitas Budi Luhur
}

\begin{abstract}
Soap opera or Electronic cinema, commonly abbreviated as sinetron, is a program which takes most portions and public interests among other television programs. A great number of spectators generate the number of its influences on society because sinetron has become one of television programs that catches public attention and is broadcasted in most hours of prime time. One of the sinetron genres is that is considered Islamic sinetron as it consists of Islamic symbols. However, it uses dialogues that do not represent Islamic values in that it consists of derogatory words expressing verbal abuse. This study aims at uncovering verbal abuse tendency of the soap opera in Tukang Bubur Naik Haji The Series aired by RCTI (Episode 296 - 407). The problem formulation is how are the tendencies of verbal abuses in the soap opera Tukang Bubur Naik Haji The Series aired by RCTI (Episode 296 407)? The objective of this research is to investigate verbal abuse in the soap opera Tukang Bubur Naik Haji The Series aired by RCTI (Episode 296 - 407). Theory and concept of the study are mass communication, mass media, television, verbal abuse. The concept of verbal abuse used in the study is in accordance to Indonesia Broadcasting Commission (KPI) Number 02/P/KPI/O3/2012 about Standard of Broadcasting Programs 2012 and types of verbal abuse. Based on the data collection and analysis, it can be concluded that verbal abuses likely used in the soap opera Tukang Bubur Naik Haji The Series aired by RCTI (episode 296 - 407) are in the category of derogatory, threatening and insulting.
\end{abstract}

Key Words : Content Analysis, Verbal Abuse, soap opera-tukang bubur naik haji-rcti

\begin{abstract}
Abstrak
Sinetron adalah tontonan televisi yang diminati dan mendominasi layar televise pada umumnya. Banyaknya penomton sinetron mempengaruhi besarnya pengaruh sinetron terhadap masyarakat karena sinetron telah menjadi salah satu tayangan televisi yang dimina dan disiarkan pada jam-jam prime time. Salah genre sinetron yang diminati adalah sinetro yang bergenre "Islami' yaitu sinetron yang isinya menggunakan simbol-simbol Islam. Namun sinetron tersebut menggunakan kata-kata yang tidak mencerminkan nilai-nilai Islam karena banyak menggunakan kata-kata kasar yang merupakan bentuk kekerasan verbal. Penelitian ini bertujuan untuk mengetahui kecenderungan kekerasan verbal pada opera sabun dari "Tukang Bubur Naik Haji The Series" di RCTI (Episode 396-407). Perumusan masalah dalam penelitian ini adalah bagaimana persentase lisan penyalahgunaan biaya kecenderungan dalam opera sabun "Tukang Bubur Naik Haji The Series" di RCTI (Episode 396-407)?. Tujuan dari penelitian ini adalah untuk mengetahui adanya pelecehan verbal dalam opera sabun "Tukang Bubur Naik Haji The Series" di RCTI (Episode 396-407). Teori dan konsep penelitian adalah komunikasi massa, media massa, televise dan pelecehan verbal. Konsep kekerasan verbal yang digunakan dalam penelitian ini dalam hal aturan Komisi Penyiaran Indonesia Nomor 02 / P / KPI / 03/2012 tentang Standar Program Siaran 2012 dan bentuk pelecehan verbal. Berdasarkan hasil pengolahan data, dapat disimpulkan bahwa pelecehan verbal dari kecenderungan muncul di sinetron "Tukang Bubur Naik Haji The Series" episode 396-407, yaitu kategori mengucapkan katakata kasar, mengancam dan menghina.
\end{abstract}

Kata Kunci : anaslisi isi. Kekerasan verbal, sinetron-tukang bubur naik jahi-rcti 


\section{Pendahuluan}

Tayangan-tayangan sinetron yang mengandung unsur kekerasan menjadi salah satu hiburan yang menarik bagi penonton. Padahal dibalik hiburan tersebut, adegan kekerasan dapat membahayakan bagi penonton khususnya anak-anak. Dalam artikel terkini (BBC Indonesia, 2013, para. 1) mengatakan bahwa Komisi Perlindungan Anak Indonesia (KPAI) mengatakan tayangan televisi termasuk berita dan sinetron merupakan faktor di balik sebagian kasus kekerasan yang dilakukan anak-anak ("Pengaruh Sinetron Terhadap Kekerasan yang Dilakukan Anak", BBC Indonesia, 2013). Contoh sinetron yang mendapat teguran dari KPI karena dinilai memperlihatkan adegan kekerasan, baik fisik maupun verbal adalah sinetron "Si Biang Kerok Cilik" di SCTV.

Hadirnya sinetron-sinetron religi juga tidak luput dari unsur kekerasan. Penelitian karya Dirhamsyah Maulana yang berjudul "Pelanggaran Etika Penyiaran Dalam Sinetron Islam KTP Studi Analisis Isi Sinetron Islam KTP Episode 185-186 Ditinjau dari Kekerasan Menurut Sunarto" membuktikan adanya kekerasan dalam sinetron "Islam KTP" dilihat dari 4 kategori, yaitu (1) Kekerasan fisik, seperti memukul 18,9\%, mencekik 5,4\%, menendang $5,40 \%$, dan melempar barang ketubuh 5,4\%; (2) Kekerasan psikologis, seperti membentak 43,2\%, menyumpah $10,8 \%$, mengancam $8,1 \%$, merendahkan $5,40 \%$, dan melecehkan 56,8\%, Kekerasan finasial, seperti tindakan mengambil 5,4\%, dan (4) Kekerasan spiritual, seperti merendahkan kepercayaan $5,4 \%$, dan merendahkan keyakinan 4\% (Dirhamsyah, 2011). Selain sinetron
"Islam KTP", peneliti mengamati kekerasan verbal terdapat dalam sinetron "Tukang Bubur Naik Haji The Series" di RCTI. Kekerasan verbal (verbal violence) dalam kepustakaan komunikasi dimaknai sebagai bentuk kekerasan yang halus; dilakukan dengan menggunakan kata-kata kasar, jorok, dan menghina (Rasyid, 2013).

Maka peneliti tertarik untuk menjadikan sinetron "Tukang Bubur Naik Haji The Series" di RCTI sebagai objek penelitian dengan menggunakan metode analisis isi kuantitatif. Penggunaan metode analisis isi dalam penelitian ini dimaksudkan untuk memudahkan dalam mengukur indikator-indikator dari isi suatu tayangan secara deskriptif. Episode tayangan yang digunakan sebagai objek penelitian yaitu episode 396-407. Pemilihan episode tersebut dikarenakan pada episode tersebut hadir tokoh atau pemeran baru yang bernama Kardun dan Romlah. Hadirnya tokoh Kardun dan Romlah ini menjadikan sinetron "Tukang Bubur Naik Haji The Series" lebih diwarnai dengan muatan kekerasan verbal. Selain tokoh Kardun dan Romlah, tokoh lainnya yang mengindikasikan perilaku kekerasan verbal adalah tokoh Haji Muhidin, Emak Enok, Aki Dawud, Malih, dan Tarmiji. Kekerasan verbal dalam penelitian ini ditinjau berdasarkan peraturan Komisi Penyiaran Indonesia Nomor 02/P/KPI/03/ 2012 tentang Standar Program Siaran tahun 2012 dan dan bentuk kekerasan menurut I. Praptama Baryadi.

Berdasarkan latar belakang masalah dan judul tersebut diatas, maka peneliti merumuskan masalah "Bagaimana persentase kecenderungan muatan kekerasan verbal dalam tayangan sinetron "Tukang Bubur Naik Haji The Series" di RCTI 
(episode 396-407)?”. Dengan tujuan penelitian adalah untuk mengetahui persentase kecenderungan muatan kekerasan verbal dalam tayangan sinetron "Tukang Bubur Naik Haji The Series" di RCTI (episode 396-407)

\section{Kerangka Teori}

Teori dan konsep penelitian yang dipergunakan dalam penelitian ini adalah Komunikasi Masaa. Menurut De Fluer, komunikasi massa adalah suatu proses dimana komunikator-komunikator menggunakan media untuk menyebarkan pesanpesan secara luas, dan secara terus menerus menciptakan makna-makna yang diharapkan dapat mempengaruhi khalayak yang besar dan berbeda-beda melalui berbagai cara (dalam Vera, 2010: 3).

Media massa merupakan istilah yang digunakan oleh publik dalam mereferensi tempat dipublikasikannya suatu informasi. Ada yang mengartikan sebagai alat untuk mentransmisikan pesan yang dilakukan komunikator yang sifatnya terlembaga. Namun sebenernya pengertian media massa itu sendiri sangat luas. Salah satu pengertian media massa adalah media komunikasi dan informasi yang melakukan penyebaran informasi secara massal dan dapat diakses oleh masyarakat secara massal pula (Bungin, 2007:72). Menurut Hafied Cangara, media massa adalah alat yang digunakan dalam penyampaian pesan dari sumber kepada khalayak (penerima) dengan menggunakan alat-alat komunikasi mekanis seperti surat kabar, film, radio, dan televise (Cangara, 2009: 142).

Media televisi pada hakekatnya merupakan suatu sistem komunikasi yang menggunakan suatu rangkaian gambar elektronik yang dipancarkan secara cepat, berurutan, dan diiringi unsur audio. Kata televisi terdiri dari kata tele yang berarti "jarak" dalam bahasa Yunani dan kata visi yang berarti "citra atau gambar" dalam Bahasa Latin. Jadi, kata televisi berarti suatu sistem penyajian gambar berikut suaranya dari suatu tempat yang berjarak jauh (Sutrisno, 1993:1).

Televisi merupakan media massa yang sangat banyak digunakan oleh masyarakat luas. Media televisi ini memiliki banyak kelebihan dibanding media lainnya. Ini dikarenakan beberapa fungsi yang melekat pada televisi. Menurut Nawiroh Vera, fungsi televisi adalah menghibur, mendidik, dan memberikan informasi sebanyak-banyaknya. Namun fungsi menghibur lebih utama dibanding yang lain (Vera, 2010: 78). Selain itu, televisi adalah media massa yang mengutamakan sajian hiburan, hampir tiga perempat bentuk siaran televisi setiap hari merupakan tayangan hiburan (Vera, 2010: 71). Pandangan mengenai televise juga disampaikan oleh Syarifudin Yunus yang mengatakan bahwa televisi memiliki fungsi yang lebih dominan pada hiburan dibanding fungsi memberi informasi dan mendidik (Yunus, 2010:27).

Ada tiga bagian dari format acara televisi yaitu drama, non drama, dan berita. Bisa juga dikategorikan menjadi fiksi, nonfiksi, dan news. Selengkapnya penjelasan sebagai berikut :

1. Fiksi (Drama)

Adalah sebuah format acara televisi yang diproduksi dan dicipta melalui proses imajinasi kreatif dari kisahkisah drama atau fiksi yang direkayasa dan dikreasi ulang. Format yang digunakan merupakan interpretasi kisah kehidupan yang 
diwujudkan dalam suatu runtutan cerita dalam sejumlah adegan. Adegan-adegan tersebut akan menggabungkan antara realitas kenyataan hidup dengan fiksi atau imajinasi khalayan para kreatornya. Contoh : drama percintaan (love story), tragedi, horor, komedi, legenda, aksi (action), sinetron, dan sebagainya.

2. Nonfiksi (Non drama)

Adalah sebuah format acara televisi yang diproduksi dan dicipta melalui proses pengolahan imajinasi kreatif dari realitas kehidupan sehari-hari tanpa harus menginterpretasi ulang dan tanpa harus menjadi dunia khalayan. Non drama bukanlah sebuah runtutan cerita fiksi dari setiap pelakunya. Untuk itu, formatformat program acara non drama merupakan sebuah runtutan pertunjukan kreatif yang mengutamakan unsur hiburan yang dipenuhi dengan aksi gaya dan music. Contoh : talkshow, konser, musik, dan variety show.

\section{Berita $(\mathrm{News})$}

Adalah sebuah format acara televisi yang diproduksi berasarkan informasi dan fakta atas kejadian dan peristiwa yang berlangsung pada kehidupan masyarakat sehari-hari. Format ini memerlukan nilai-nilai faktual dan aktual yang disajikan dengan ketepatan dan kecepetan waktu dimana dibutuhkan sifat liputan yang independen. Contoh : berita ekonomi, politik, sosial, budaya, dan laporan olahraga (Rukmananda, 2004: 65-66).

\section{Analisis Isi}

Analisis isi kuantitatif dapat didefinisikan sebagai suatu teknik penelitian ilmiah yang ditujukan untuk mengetahui gambaran karakteristik isi dan menarik inferensi dari isi. Analisis isi ditujukan untuk mengidentifikasi secara sistematis isi komunikasi yang tampak (manifest), dan dilakukan secara objektif, valid, reliabel, dan dapat direplikasi (Eriyanto, 2011: 15).

Menurut Holsti yang dikutip Eriyanto, definisi analisis isi adalah suatu teknik penelitian untuk membuat inferensi yang dilakukan secara objektif, identifikasi, dan sistematis dari karakteristik pesan (Eriyanto, 2011: 15). Burhan Bungin mengatakan bahwa dikalangan ilmuan sosial, metode analisi isi merupakan suatu metode yang amat efisien untuk menginvestigasi isi media baik yang tercetak maupun media dalam bentuk broadcast (Bungin, 2011: 185).

Metode analisis isi merupakan suatu teknik sistemik untuk menganalisis pesan dan mengolah pesan, atau suatu alat untuk mengobservasi dan menganalisis isi perilaku komunikasi yang terbuka dari komunikator yang dipilih (Bungin, 2011:185). Menurut Wimmer \& Dominick (2000) tujuan analisis isi adalah :

1. Menggambarkan isi komunikasi Yaitu mengungkap kecenderungan yang ada pada isi komunikasi, baik melalui media cetak maupun elektronik.

2. Menguji hipotesis tentang karakteristik pesan

Yaitu sejumlah periset berusaha menghubungkan karakteristik tertentu dari komunikator (sumber) 
dengan karakteristik pesan yang dihasilkan.

3. Membandingkan isi media dengan dunia nyata.

Memperkirakan gambaran media terhadap kelompok tertentu di masyarakat.

4. Mendukung studi efek media massa

Yaitu untuk melihat apakah pesanpesan di media massa tersebut menumbuhkan sikap-sikap yang serupa di antara para pengguna media yang berat (heavy users) (Sobur, 2011: 230-231).

Dilihat dari pendekatan dalam analisis isi, dapat dibagi kedalam tiga bagian besar, yakni analisis isi deksriptif, eksplanatif, dan prediktif. Berikut pengertian ketiganya :

\section{Analisis Isi Deskriptif}

Analisis isi deskriptif adalah analisis isi yang dimaksudkan untu menggambarkan secara detail suatu pesan, atau suatu teks tertentu. Desain analisis isi ini tidak dimaksudkan untuk menguji suatu hipotesis tertentu, atau menguji hubungan diantara variabel. Analisis isi semata untuk deskripsi, menggambarkan aspekaspek dan karakteristik dari suatu pesan.

2. Analisis Isi Eksplanatif

Analisis isi eksplanatif adalah analisis isi yang didalamnya terdapat pengujian hipotesis tertentu. Analisis isi ini juga mencoba membuat hubungan antara satu variabel dan variabel lain. Analisis tidak hanya sebatas menggambarkan secara deskriptif isi dari suatu pesan, tetapi juga mencoba mencari hubungan antara isi pesan ini dan variabel lain.

3. Analisis isi Prediktif

Analisis isi prediktif berusaha untuk memprediksi hasil seperti tertangkap dalam analisis isi dengan variabel lain. Disini peneliti bukan hanya menggunakan variabel lain diluar analisis isi, tetapi juga harus menggunakan hasil penelitian dari metode lain-seperti survey eksperimen. Data dari dua hasil penelitian (analisis isi dan metode lain) itu dihubungkan, dan dicari keterkaitannya (Eriyanto, 2011: 45-53).

\section{Sinetron}

Sinetron merupakan drama yang menyajikan cerita berbagai tokoh secara bersamaan. Masing-masing tokoh memiliki alur cerita mereka sendiri-sendiri tanpa harus dirangkum menjadi suatu kesimpulan. Akhir cerita sinetron cenderung selalu terbuka dan sering kali tanpa penyelesaian (open-ended). Cerita cenderung dibuat berpanjang-panjang selama masih ada audiens yang menyukainya (Morrisan, 2008: 223).

Sinetron sebagai salah satu bentuk tayangan televisi memiliki kelebihankelebihan sebagai berikut :

1. Bersifat audio visual yaitu selain mampu menyuguhkan gambar, sinetron juga mampu menampilkan suara. Karena pada dasarnya sinetron adalah 
gabungan dari gambar, suara, dan cerita.

2. Diterima oleh segala lapisan masyarakat yaitu sinetron dapat dinikmati siapa saja, tidak membedakan latar belakang pendidikan dan budaya.

3. Dapat dinikmati oleh berbagai bangsa melalui bahasa, karena bahasa merupakan alat komunikasi.

4. Dapat diputar berulang-ulang yaitu dapat dinikmati kapan saja tanpa terbatas ruang dan waktu.

5. Penyajian melalui gambar yang hidup, sinetron pada dasarnya adalah Motion Picture atau gambar bergerak.

6. Memiliki gaya visual yaitu mempunyai kemampuan untuk mempertunjukkan sesuatu (Dahlan, 1980).

\section{Komunikasi Verbal}

Kata atau istilah komunikasi (dari bahasa inggris "communication"), secara epistemologis atau menurut asal katanya adalah dari bahasa latin communicatus, dan perkataan ini bersumber pada kata communis. Kata communis memiliki makna "berbagi" atau "menjadi milik bersama" yaitu usaha yang memiliki tujuan untuk kebersamaan atau kesamaan makna. Komunikasi secara terminologis merujuk pada adanya proses penyampaian suatu pernyataan oleh seseorang kepada orang lain. Jadi, yang terlibat dalam komunikasi ini adalah manusia (Rahayu Ginintasasi, n.d.).

Simbol atau pesan verbal adalah semua jenis simbol yang menggunakan satu kata atau lebih (Mulyana, 2010:260). Suatu sistem kode verbal disebut bahasa. Bahasa dapat didefinisikan sebagai seperangkat simbol, dengan aturan untuk mengkombinasikan simbol-simbol tersebut, yang digunakan dan dipahami suatu komunitas. Bahasa verbal adalah sarana utama untuk menyatakan pikiran, perasaan, dan maksud kita. Bahasa verbal menggunakan kata-kata yang merepresentasikan berbagai aspek realitas individual kita (Mulyana, 2010:260-261).

\section{Kekerasan Verbal}

Menurut Moore \& Fine (dikutip oleh Lili 2009) mendefinisikan agresi sebagai tingkah laku kekerasan secara fisik seperti memukul ataupun secara verbal berupa penggunan kata-kata kasar terhadap individu lain atau terhadap objek-objek (Lili Hartini, 2009:2). Kekerasan verbal (verbal violence) dalam kepustakaan komunikasi dimaknai sebagai bentuk kekerasan yang halus; dilakukan dengan menggunakan kata-kata kasar, jorok, dan menghina (Rasyid, 2013: 95).

Kekerasan emosional atau psikologis atau verbal tidak dapat menimbulkan akibat langsung tapi dampaknya dapat memutus-asakan apabila berlangsung berulang-ulang. Termasuk dalam kekerasan emosional ini adalah penggunaan kata-kata kasar, merendahkan, atau mencemooh (Su'adah, 2005: 95).

Menurut Buss dalam Myers, bentuk verbal dari agresi melibatkan usaha untuk menyakiti orang lain melalui katakata, bukan melalui perbuatan (Myers, 2010: 116). Adapun bentuk kekerasan verbal menurut I. Praptama Baryadi terwujud dalam tindak tutur seperti memaki, membentak, mengancam, menghujat, mengejek, melecehkan, menjelek- 
jelekkan, mengusir, memfitnah, menyudutkan, mendis-kriminasikan, mengintimidasi, menakut-nakuti, memaksa, menghasut, membuat orang lain malu, menghina, dan lain sebagainya (Suparno, 2002: 83).

Jika kategori kekerasan verbal mengacu pada peraturan Komisi Penyiaran Indonesia Nomor 02/P/KPI/03/2012 tentang Standar Program Siaran tahun 2012 dapat dikategorikan sebagai berikut (Standar Program Siaran 2012, Bab XI \& XIII, hal. 51-55):

a. Penyebutan terhadap seseorang atau kelompok tertentu dengan maksud menghina atau melecehkan seseorang atau kelompok tertentu. Hal tersebut mengacu pada Bab XI (sebelas) SPS pasal 17 mengenai perlindungan kepada orang dan masyarakat tertentu, yang berbunyi :
(1) Program siaran dilarang menampilkan muatan yang melecehkan orang dan/atau kelompok masyarakat tertentu.

(2) Orang dan/atau kelompok tertentu sebagaimana yang dimaksud pada ayat (1) antara lain, tetapi tidak terbatas:

i.Pekerja tertentu, seperti: pekerja rumah tangga, hansip, pesuruh kantor, pedagang kaki lima, satpam;

ii. Orang dengan orientasi seks dan identitas gender tertentu;

iii.Lanjut usia, janda, duda;

iv.Orang dengan kondisi fisik tertentu, seperti gemuk, ceking, cebol, bibir sumbing, hidung pesek, memiliki gigi tonggos, mata juling;
v.Tunanetra, tunarungu, tuna-wicara, tunadaksa, tunagrahita, autis;

vi.Pengidap penyakit tertentu, seperti HIV/AIDS, kusta, epilepsi, Alzheimer, latah; dan atau

vii.Orang dengan masalah kejiwaan.

b. Penggunaan bahasa verbal, seperti mengucapkan kata-kata kasar dan makian. Hal tersebut mengacu pada Bab XIII (tigabelas) SPS mengenai pelarangan dan pembatasan kekerasan bagian kedua pasal 24 tentang ungkapan kasar dan makian, yang berbunyi :

(1) Program Siaran dilarang menampilkan ungkapan kasar dan makian, baik secara verbal maupun nonverbal, yang mempunyai kecenderungan menghina atau merendahkan martabat manusia, memiliki makna jorok/ mesum/ cabul/vulgar, dan/atau menghina agama dari Tuhan.

(2) Kata-kata kasar dan makian sebagaimana yang dimaksud pada ayat (1) di atas mencakup kata-kata dalam bahasa Indonesia, bahasa daerah, dan bahasa asing.

c. Mengenai jam tayang. Hal tersebut mengacu pada Bab XIII (tigabelas) SPS mengenai pelarangan dan pembatasan kekerasan bagian ketiga pasal 25 tentang pembatasan program bermuatan kekerasan, yang berbunyi : "Promo program siaran yang mengandung muatan adegan kekerasan dibatasi hanya boleh 
disiarkan pada klasifikasi D, pukul 22.00 - 03.00 waktu setempat".

\section{Metode Penelitian}

Penelitian ini menggunakan paradigma positivisme. Pendekatan yang digunakan merupakan pendekatan kuantitatif dengan jenis penelitian deskriptif. Pendekatan kuantitatif adalah pendekatan yang menggambarkan atau menjelaskan suatu masalah yang hasilnya dapat digeneralisasikan. Dalam pendekatan kuantitatif, peneliti dituntut untuk bersikap objektif dan memisahkan diri dari data (Kriyantono,2010:55). Metode penelitian yang digunakan yaitu metode analisis isi. Menurut Holsti (1969, dalam Eriyanto, 2011:15) definisi analisis isi adalah suatu teknik penelitian untuk membuat inferensi yang dilakukan secara objektif dan identifikasi sistematis dari karkteristik pesan.

Objek penelitian ini adalah kekerasan verbal dalam sinetron "Tukang Bubur Naik Haji The Series" yang hadir setiap hari Senin - Minggu pada pukul 20.00 - 23.00 WIB di stasiun televisi RCTI. Tayangan ini berdurasi 180 menit (tiga jam) yang diselingi dengan tayangan iklan (Commercial Break).
Definisi populasi menurut Eriyanto adalah semua anggota dari objek yang ingin kita ketahui isinya. Populasi adalah konsep yang asbtrak. Karena itu, populasi harus didefinisikan secara jelas agar anggota dari populasi dapat ditentukan secara cermat (Eriyanto, 2011:109). Populasi dalam penelitian ini mencakup seluruh tayangan sinetron "Tukang Bubur Naik Haji The Series" episode 396-407. Adapun rancangan sampel non probabilitas yang dipilih oleh peneliti adalah sampel purposive (purposive sampling). Teknik ini mencakup objekobjek yang diseleksi atas dasar kriteriakriteria tertentu yang dibuat periset berdasarkan tujuan riset (Kriyantono, 2010: 158).

\section{Operasional Variabel}

Proses operasional adalah kegiatan menurunkan abstrak ke konkret. Hal ini karena analisis isi hanya dapat dilakukan dengan mengamati aspek-aspek yang konkret yang terlihat nyata dan dapat diobservasi oleh peneliti. Konsep yang abstrak karenanya dioperasionalisasikan menjadi indikator-indikator yang diamati secara empiris (Eriyanto, 2011:177). 
Tabel 3.2

KATEGORI KEKERASAN VERBAL

\begin{tabular}{|c|c|c|}
\hline No. & Kategori Kekerasan Verbal & Indikator \\
\hline 1. & Mengucapkan kata-kata kasar & $\begin{array}{ll}\text { - } & \text { Sialan } \\
\text { - } & \text { Goblok } \\
\text { - } & \text { Ga ada otaknya } \\
\text { - } & \text { Bacot } \\
\text { - } & \text { Gelo } \\
\text { - } & \text { Kampret } \\
\text { - } & \text { Geblek } \\
\text { - } & \text { Blo'on } \\
\text { - } & \text { Sapi } \\
\text { - } & \text { Kutu kupret } \\
\text { - } & \text { Biadab }\end{array}$ \\
\hline 2. & $\begin{array}{l}\text { Mengancam : Usaha untuk menakut-nakuti } \\
\text { agar korban mengikuti hal-hal yang pelaku } \\
\text { inginkan. }\end{array}$ & $\begin{array}{ll}\text { - } & \text { Gue ketok nih } \\
\text { - } & \text { Gue gampar lu } \\
\text { - } & \text { Gue keplak nih } \\
\text { - } & \text { Gue tempeleng lu } \\
\text { - } & \text { Gue tabokin lu } \\
\text { - } & \text { Gue sodok mata lu } \\
\text { - } & \text { Gue sambit nih } \\
\text { - } & \text { Gue hajar } \\
\text { - } & \text { Tak plintir leher sampean }\end{array}$ \\
\hline 3. & $\begin{array}{l}\text { Menghina : Usaha untuk menjelek-jelekkan } \\
\text { status sosial atau kekurangan orang lain. }\end{array}$ & $\begin{array}{ll}\text { - } & \text { Pe'ak (pendek akal) } \\
\text { - } & \text { Sarap } \\
\text { - } & \text { Darah blangsak } \\
\text { - } & \text { Nenek peyot } \\
\text { - } & \text { Iblis } \\
\text { - } & \text { Tua bangka } \\
\text { - } & \text { Orang susah } \\
\text { - } & \text { Orang gila } \\
\text { - } & \text { Orang kampong }\end{array}$ \\
\hline
\end{tabular}

\section{Hasil Penelitian}

Hal yang dilakukan peneliti untuk memperoleh frekuensi kemunculan adegan kekerasan verbal, peneliti melakukan pencatatan pada setiap episode yang telah dijadikan sampel dalam penelitian ini, yaitu episode $396-407$. 
Tabel 4.1

FREKUENSI ADEGAN KEKERASAN VERBAL DALAM TAYANGAN "TUKANG BUBUR NAIK HAJI THE SERIES” DI RCTI (EPISODE 396-407)

\begin{tabular}{|c|l|c|c|}
\hline No. & \multicolumn{1}{|c|}{ Kategorisasi } & Frekuensi & Persentase (\%) \\
\hline 1. & Mengucapkan Kata-Kata Kasar & 56 & $15 \%$ \\
\hline 2. & Mengancam & 40 & $10,7 \%$ \\
\hline 3. & Menghina & 278 & $74,3 \%$ \\
\hline \multicolumn{2}{|c|}{ Jumlah } & 374 & $100 \%$ \\
\hline
\end{tabular}

Sumber: Alvionita Choirun Nisa, 2013

Tabel 4.2

FREKUENSI ADEGAN MENGUCAPKAN KATA-KATA KASAR DALAM TAYANGAN "TUKANG BUBUR NAIK HAJI THE SERIES" DI RCTI (EPISODE 396-407)

\begin{tabular}{|c|l|c|c|}
\hline No. & \multicolumn{1}{|c|}{ Indikator } & Frekuensi & Persentase (\%) \\
\hline 1. & Sialan & 10 & $17,8 \%$ \\
\hline 2. & Goblok & 8 & $14,3 \%$ \\
\hline 3. & Ga ada otaknya & 8 & $14,3 \%$ \\
\hline 4. & Bacot & 12 & $21,4 \%$ \\
\hline 5. & Gelo & 2 & $3,6 \%$ \\
\hline 6. & Kampret & 6 & $3,6 \%$ \\
\hline 7. & Geblek & 2 & $10,7 \%$ \\
\hline 8. & Blo'on & 2 & $3,6 \%$ \\
\hline 9. & Sapi & 2 & $3,6 \%$ \\
\hline 10. & Kutu Kupret & 2 & $3,6 \%$ \\
\hline 11. & Biadab & 56 & $3,6 \%$ \\
\hline \multicolumn{3}{|c|}{ Jumlah } & $100 \%$ \\
\hline
\end{tabular}

Sumber: Alvionita Choirun Nisa, 2013

Tabel 4.3

\section{FREKUENSI ADEGAN MENGANCAM DALAM TAYANGAN "TUKANG BUBUR NAIK HAJI THE SERIES" DI RCTI (EPISODE 396-407)}

\begin{tabular}{|c|l|c|c|}
\hline No. & \multicolumn{1}{|c|}{ Indikator } & Frekuensi & Persentase (\%) \\
\hline 1. & Gue ketok nih & 14 & $35 \%$ \\
\hline 2. & Gue gampar lu & 6 & $15 \%$ \\
\hline 3. & Gue keplak nih & 4 & $10 \%$ \\
\hline 4. & Gue tempeleng lu & 2 & $5 \%$ \\
\hline 5. & Gue tabokin lu & 6 & $15 \%$ \\
\hline 6. & Gue sodok mata lu & 2 & $5 \%$ \\
\hline 7. & Gue sambit nih & 2 & $5 \%$ \\
\hline 8. & Gue hajar & 2 & $5 \%$ \\
\hline 9. & Tak plintir leher sampean & 40 & $5 \%$ \\
\hline & Jumlah & $100 \%$ \\
\hline
\end{tabular}

Sumber: Alvionita Choirun Nisa, 2013 
Tabel 4.4

FREKUENSI ADEGAN MENGHINA DALAM TAYANGAN "TUKANG BUBUR NAIK HAJI THE SERIES" DI RCTI

(EPISODE 396-407)

\begin{tabular}{|c|l|c|c|}
\hline No. & \multicolumn{1}{|c|}{ Indikator } & Frekuensi & Persentase (\%) \\
\hline 1. & Pe'ak (Pendek Akal) & 182 & $65,4 \%$ \\
\hline 2. & Sarap & 64 & $23,0 \%$ \\
\hline 3. & Darah blangsak & 2 & $0,7 \%$ \\
\hline 4. & Nenek peyot & 4 & $1,4 \%$ \\
\hline 5. & Iblis & 2 & $0,7 \%$ \\
\hline 6. & Tua bangka & 4 & $1,4 \%$ \\
\hline 7. & Orang susah & 4 & $1,4 \%$ \\
\hline 8. & Orang gila & 12 & $4,3 \%$ \\
\hline 9. & Orang kampung & 278 & $1,4 \%$ \\
\hline \multicolumn{2}{r|}{ Jumlah } & $\mathbf{2 0 1 3}$ \\
\hline
\end{tabular}

Sumber: Alvionita Choirun Nisa, 2013

\section{Pembahasan}

Pada penelitian ini membuktikan bahwa tayangan sinetron "Tukang Bubur Naik Haji The Series" episode 396 - 407 terbukti terdapat muatan kekerasan verbal dengan kategori kekerasan verbal yang paling dominan muncul adalah kategori menghina sebesar 74,3\%, kemudian kategori mengucapkan kata-kata kasar memperoleh persentase sebesar $15 \%$, dan kategori kekerasan verbal yang paling jarang muncul adalah kategori mengancam sebesar $10,7 \%$. Pada penelitian ini terdapat kelemahan dan keterbatasan. Kelemahan penelitian ini yaitu tidak dilakukannya penarikan sampel acak karena jumlah populasi yang terlalu besar sehingga peneliti menentukan jumlah populasi untuk diriset berdasarkan pertimbangan ilmiah. Sedangkan keterbatasan dalam penelitian ini adalah penelitian ini hanya memfokuskan untuk mengetahui gambaran karakteristik isi pesan kekerasan verbal dalam tayangan "Tukang Bubur Naik Haji The Series" dan membuat deskripsi untuk menggambarkan realitas yang sedang terjadi. Selain itu, peneliti tidak dapat menganalisa semua tayangan sinetron "Tukang Bubur Naik Haji The Series" dikarenakan jumlah populasi tayangan yang terlalu besar, sehingga peneliti hanya menentukan 5 tayangan untuk dianalisis.

Dalam penelitian ini, peneliti menggunakan objek penelitian tayangan sinetron "Tukang Bubur Naik Haji The Series". Tujuan peneliti adalah untuk mengetahui adanya kekerasan verbal dalam sinetron tersebut. Tayangan sinetron "Tukang Bubur Naik Haji The Series" adalah salah satu drama seri religi yang ditayangkan oleh stasiun televisi swasta RCTI yang hadir setiap hari pukul 20.30 22.00 WIB. Sinetron ini berhasil memperoleh piala penghargaan Panasonic Gobel Awards tahun 2013 dengan kategori Drama Seri Tervaforit. Hal tersebut membuktikan bahwa tayangan sinetron "Tukang Bubur Naik Haji The Series" berhasil menarik perhatian penontonnya.

Sinetron "Tukang Bubur Naik Haji The Series" merupakan pengembangan cerita FTV "Tukang Bubur Naik Haji" 
yang sebelumnya sudah pernah ditayangkan oleh RCTI, menceritakan kehidupan seorang tukang bubur bernama Sulam yang berniat memberangkatkan ibadah Haji ibunya. Sehari-hari, Sulam berjualan bubur keliling dengan gerobak dorongnya. Usahanya dalam mencapai keinginannya untuk memberangkatkan ibadah Haji ibunya memang tidak lah mudah. Belum lagi tanggapan sinis, olokolok, dan cemoohan dari warga kampung mendengar niatan Sulam tersebut, terutama tetangga Sulam yang bernama Haji Muhidin dan Hajah Maemunah. Haji Muhidin dan Haji Maemunah merupakan suami istri yang sudah menunaikan ibadah Haji dan termasuk orang yang terpandang di kampungnya. Mendengar niatan Sulam yang ingin memberangkatkan Haji ibunya, membuat mereka tertawa sinis dan tak henti-hentinya mencemooh keluarga Sulam. Tetapi dengan kesabaran dan keikhalasan Sulam, serta doa ibunya, akhirnya niatan Sulam untuk memberangkatkan Haji ibunya tercapai. Bahkan tidak hanya ibunya saja yang berangkat Haji, Sulam dan istrinya yaitu Rodiah pun ikut menunaikan rukun Islam yang kelima. Semenjak saat itu, warung bubur Sulam pun laris dan Ia membuka usaha warung bubur di rumahnya.

Tokoh utama dalam sinetron "Tukang Bubur Naik Haji The Series" yaitu Haji Sulam yang memiliki usaha warung bubur di rumahnya. Haji Sulam merupakan bagian dari tokoh protagonis yang memiliki sifat sabar, ikhlas, bersahaja, rendah hati, dermawan, dan pemaaf. Tetapi beberapa bulan belakangan ini tokoh Sulam tidak dihadirkan, sebab dalam sinetron diceritakan bahwa Haji Sulam membuka usaha warung bubur di Negara Arab Saudi. Padahal kehadiran tokoh Haji Sulam dalam sinetron "Tukang Bubur Naik Haji The Series" bisa dijadikan contoh yang baik bagi masyarakat dikarenakan sifatnya yang sabar, ikhlas, bersahaja, rendah hati, dermawan, dan pemaaf. Berbeda dengan tokoh Haji Muhidin yang memiliki sifat sebaliknya, menunaikan ibadah Haji karena ingin mendapat pujian dari orang lain, sombong, iri apabila melihat orang lain lebih sukses dari dirinya, pelit, dan suka menghina orang lain. Tokoh Haji Muhidin seakan menjadi penyeimbang dari tokoh Haji Sulam, sehingga dapat terlihat perbedaan dari keduanya, mana Haji yang mabrur dan yang tidak.

Sinetron "Tukang Bubur Naik Haji The Series" melanjutkan cerita FTV-nya terdahulu. Dalam sinetron tersebut menyuguhkan nuansa-nuansa Islami, seperti ajaran-ajaran agama Islam yang disampaikan melalui dakwah atau dialog dari para pemainnya, dan dikemas dalam bentuk komedi guna menghibur masyarakat yang menontonnya. Hal ini menjadi nilai positif bagi sinetron "Tukang Bubur Naik Haji The Series" mengingat mayoritas masyarakat Indonesia beragama Islam. Maka dengan hadirnya sinetron tersebut diharapkan mampu menambah pengetahuan masyarakat, khususnya pemeluk agama Islam mengenai ajaran-ajaran agama Islam. Namun sangat disayangkan, sinetron dengan latar belakang religi ini mengandung adegan kekerasan verbal dari beberapa pemerannya. Walaupun memang tidak semua adegan dalam sinetron "Tukang Bubur Naik Haji The Series" mengandung unsur kekerasan verbal.

Kekerasan verbal yang terdapat dalam sinetron "Tukang Bubur Naik Haji The Series" memang bukan kasus pertama 
dalam industri hiburan media televisi di Indonesia. Sebelumnya, sinetron "Islam KTP" yang tayang di SCTV juga terbukti mengandung unsur kekerasan berdasarkan hasil penelitian yang dilakukan oleh Dirhamsyah Maulana dengan judul "Pelanggaran Etika Penyiaran Dalam Sinetron Islam KTP Studi Analisis Isi Sinetron Islam KTP Episode 185-186 Ditinjau dari Kekerasan Menurut Sunarto". Selain itu, sinetron "Si Biang Kerok Cilik" di SCTV sempat dilaporkan ke KPI karena dinilai mengandung kekerasan verbal. Jika dilihat dari ketiga kasus kekerasan yang terdapat dalam sinetron tersebut, tidak mengherankan apabila tayangan kekerasan sudah dianggap biasa oleh sebagian masyarakat yang belum kritis dan bijak dalam memilah program acara di televisi.

Dalam penelitian ini, peneliti menentukan tiga kategorisasi sesuai Pedoman Perilaku Penyiaran dan Standar Program Siaran (P3 SPS), yaitu mengucapkan kata-kata kasar, mengancam, dan menghina. Dari lima tayangan "Tukang Bubur Naik Haji The Series" di RCTI yang dijadikan sampel penelitian ini terbukti bahwa sinetron tersebut mengandung adanya kekerasan verbal, seperti mengucapkan kata-kata kasar, mengancam, dan menghina. Dari hasil penelitian menunjukkan jenis kategorisasi kekerasan verbal yang lebih dominan adalah kategorisasi menghina sebesar $74,3 \%$.

Jenis kategorisasi menghina terbagi atas beberapa indikator, yaitu menghina dengan sebutan pe'ak (pendek akal), sarap, darah blangsak, nenek peyot, iblis, tua Bangka, orang susah, orang gila, dan orang kampung. Berikut beberapa potongan adegan yang memperlihatkan adegan menghina dalam tayangan "Tukang Bubur
Naik Haji The Series" di RCTI seperti dibawah ini :

Untuk lebih rinci mengenai jenis kategorisasi menghina yang sering muncul dalam tayangan ini adalah jenis menghina dengan sebutan pe'ak (pendek akal) sebesar $65,4 \%$. Sedangkan kategori menghina dengan sebutan sarap sebesar $23,0 \%$. Diikuti dengan kategorisasi dengan sebutan orang gila sebesar $4,3 \%$, sebutan nenek peyot, tua bangka, orang susah, orang kampung, masing-masing sebesar $1,4 \%$, sebutan darah blangsak dan iblis, masing-masing sebesar $0,7 \%$.

Dari rincian indikator dari kategorisasi menghina diatas, dapat dinyatakan bahwa tayangan "Tukang Bubur Naik Haji The Series" di RCTI terdapat muatan adegan kekerasan verbal berupa menghina hampir di setiap episodenya. Padahal dampak dari perbuatan menghina dapat menimbulkan gangguan psikis atau hilangnya rasa percaya diri pada seseorang yang mengalaminya. Tetapi dalam tayangan ini kata "pe'ak" lebih dominan muncul.

Mengacu pada Pedoman Perilaku Penyiaran dan Standar Program Siaran (P3SPS), jenis kategorisasi menghina pada tayangan "Tukang Bubur Naik Haji The Series" termasuk melanggar pasal-pasal yang telah ditetapkan oleh KPI dalam Standar Program Siaran pada Bab Sebelas mengenai Perlindungan Kepada Orang dan Mayarakat Tertentu pasal 17 , yang berbunyi : "Pertama, Program siaran dilarang menampilkan muatan yang melecehkan orang dan/atau kelompok masyarakat tertentu. Kedua, Orang dan/atau kelompok masyarakat tertentu bagaimana yang dimaksud pada ayat (1) antara lain, tetapi tidak terbatas: 
a. Pekerja tertentu, seperti: pekerja rumah tangga, hansip, pesuruh kantor, pedagang kaki lima, satpam;

b. Orang dengan orientasi seks dan identitas gender tertentu;

c. Lanjut usia, janda, duda;

d. Orang dengan kondisi fisik tertentu, seperti gemuk, ceking, cebol, bibir sumbing, hidung pesek, memiliki gigi tonggos, mata juling;

e. Tunanetra, tunarungu, tunawicara, tunadaksa, tunagrahita, autis;

f. Pengidap penyakit tertentu, seperti: HIV/AIDS,kusta, epilepsy, Alzheimer, latah; dan/atau

g. Orang dengan masalah kejiwaan."

Jika penelitian ini dikaitkan dengan peraturan Komisi Penyiaran Indonesia Nomor 02/P/KPI/03/2012 tentang Standar Program Siaran tahun 2012 tayangan "Tukang Bubur Naik Haji The Series" terbukti melanggar pasal-pasal yang sudah ditetapkan dalam Standar Program Siaran 2012, diantaranya :

1. Bab Sebelas mengenai Perlindungan Kepada Orang dan Mayarakat Tertentu, pasal 17.

2. Bab Tigabelas mengenai Pelarangan dan Pembatasan Kekerasan, Bagian Kedua tentang Ungkapan Kasar dan Makian, pasal 24.

3. Bab Tigabelas mengenai Pelarangan dan Pembatasan Kekerasan, Bagian Ketiga, pasal 25.
Oleh karenya berdasarkan aturan yang telah ditetapkan oleh KPI mengenai Standar Program Siaran (SPS) tentang Perlindungan kepada Orang dan Masyarakat Tertentu, tayangan "Tukang Bubur Naik Haji The Series" di RCTI dengan jenis kategorisasi menghina telah melanggar peraturan, sebab hampir semua indikator dari kategorisasi menghina yang sudah diteliti menunjukkan bahwa dari 9 (Sembilan) indikator masing-masing dinyatakan memiliki hasil nilai persentase. Selain jenis kategorisasi menghina, dalam tayangan "Tukang Bubur Naik Haji The Series" juga terdapat bentuk kekerasan verbal lain dengan jenis kategorisasi mengucapkan kata-kata kasar dan mengancam. Seperti yang telah dijelaskan pada hasil penelitian bahwa kategorisasi mengucapkan kata-kata kasar juga sering muncul dalam tayangan ini dengan persentase sebesar $15 \%$.

Untuk lebih rinci mengenai jenis kategorisasi mengucapkan kata-kata kasar yang sering muncul dalam tayangan ini adalah mengucapkan kata-kata kasar berupa kata bacot sebesar 21,4\%. Sedangkan kategori mengucapkan katakata kasar berupa kata sialan sebesar 17,8 $\%$. Diikuti dengan kata goblok, ga ada otaknya, masing-masing sebesar sebesar $14,3 \%$, kata geblek sebesar 10,7\%, kata gelo, kampret, blo'on, sapi, kutu kupret, dan biadab, masing-masing sebesar 3,6 \%. Dengan begitu, dapat dinyatakan bahwa tayangan "Tukang Bubur Naik Haji The Series" di RCTI terdapat muatan adegan kekerasan verbal berupa mengucapkan kata-kata kasar hampir di setiap episodenya.

Peraturan yang tertulis di P3SPS mengenai Pelarangan dan Pembatasan Kekerasan, seperti yang telah dijelaskan 
diatas membuktikan bahwa tayangan "Tukang Bubur Naik Haji The Series" di RCTI telah melanggar pasal-pasal tersebut. Hampir semua indikator dari kategorisasi mengucapkan kata-kata kasar dalam tayangan "Tukang Bubur Naik Haji The Series" menunjukkan bahwa dari 11 (sebelas) indikator memiliki hasil nilai persentase.

Indikator dari kategorisasi mengancam berupa kalimat "gue ketok nih" merupakan kalimat yang dominan muncul dalam tayangan "Tukang Bubur Naik Haji The Series" dengan persentase sebesar $35 \%$. Kategorisasi mengancam berupa kalimat "gue gampar lu”, "gue tabokin lu”, masing-masing sebesar $15 \%$, kalimat "gue keplak nih" sebesar $10 \%$, kalimat "gue tempeleng lu", "gue sodok mata lu”, "gue sambit nih", "gue hajar", dan "tak plintir leher sampean", masingmasing sebanyak $5 \%$.

Pada bulan Januari, tayangan "Tukang Bubur Naik Haji The Series" hadir pada pukul 19.00 - 22.00 WIB. Jam tayang tersebut termasuk kedalam kategori prime time. Jika hal ini dikaitkan dengan Standar Program Siaran mengenai Pelarangan dan Pembatasan Kekerasan pasal 25 Bagian Ketiga yaitu "Promo program siaran yang mengandung muatan adegan kekerasan dibatasi hanya boleh disiarkan paa klasifikasi D, pukul 22.00 03.00 waktu setempat”. Berdasarkan keterngan tersebut, dapat dinyatakan bahwa tayangan "Tukang Bubur Naik Haji The Series" telah melanggar peraturan P3SPS yang telah ditentukan oleh KPI.
Berdasarkan hasil data dan analisis data makasnagat jelas dan kuat bahwa sinetron "Tukang Bubur Naik Haji"

\section{Kesimpulan}

Berdasarkan haisl penelitian yang sudah dijelaskan sebelumnya maka penelitian ini dapat disimpulan bahwa Persentase data dan frekuensi dari kategori kekerasan verbal yang paling dominan muncul dalam tayangan sinetron "Tukang Bubur Naik Haji The Series" di RCTI periode 22-26 Januari 2013, yaitu kategori menghina dengan frekuensi kemunculan 278 dan persentase sebesar 74,3\%. Indikator dari kategori menghina yang dominan muncul adalah sebutan "pe'ak" (pendek akal) dengan frekuensi 182 dan persentase sebesar 65,4\% dalam setiap penayangan "Tukang Bubur Naik Haji The Series" episode 396 - 407. Pada Kategori mengucapkan kata-kata kasar memperoleh frekuensi 56 dan persentase sebesar $15 \%$. Untuk indikator mengucapkan kata-kata kasar yang paling dominan muncul adalah kata "bacot" dengan frekuensi 12 dan persentase sebesar 21,4 \%. Kemudian untuk kategori mengancam memperoleh frekuensi 40 dan persentase sebesar 10,7 $\%$. Untuk indikator dari kategori mengancam yang sering muncul dalam tayangan "Tukang Bubur Naik Haji The Series" episode 396 - 407 oleh kalimat "gue ketok nih" dengan frekuensi 14 dan persentase sebesar $35 \%$. 


\section{DAFTAR PUSTAKA}

\section{BUKU}

Ardianto, Elvinaro dkk. 2007. Komunikasi Massa: Suatu Pengantar.

Bandung: Simbiosa Rekatama Media.

Aceng, dkk. 2011. Filsafat Ilmu Lanjutan. Jakarta: Kencana Prenada Media Group.

------. 2007. Pengantar Ilmu Komunikasi. Jakarta: PT. Raja Grafindo Persada.

Bungin, Burhan. 2007. Pengantar Ilmu Komunikasi. Jakarta: PT. Raja Grafindo Persada

Bungin, Burhan (Ed). 2011. Metodologi Penelitian Kualitatif: Aktualisasi Metodologis ke Arah Ragam Varian Kontemporer. Jakarta: Rajawali Pers Cangara, Hafied. 2009. Pengantar Ilmu Komunikasi. Jakarta: Rajawali Pers.

David.G, Myers. 2010. Psikologi Sosial. Jakarta: Salemba Humanika.

Effendy, Onong Uchjana . 2002. Dinamika Komunikasi. Bandung: Remaja Rosdakarya.

Eriyanto. 2011. Analisis Isi: Pengantar Metodologi Penelitian Ilmu Komunikasi dan Ilmu-Ilmu Sosial Lainnya. Jakarta: Kencana Prenada Media Group.

Kamus Besar Bahasa Indonesia Edisi Kedua. 1995. Jakarta: Balai Pustaka.
Kriyantono, Rachmat. 2010. Teknik Praktis Riset Komunikasi. Jakarta: Kencana Prenada Media Group.

Morrisan. 2008. Manajemen Media Penyiaran: Strategi Mengelola Radio dan Televisi. Jakarta: Kencana Prenada Media Group.

Mulyana, Deddy. 2010. Ilmu Komunikasi Suatu Pengantar. Bandung: PT. Remaja Rosdakarya.

Rasyid, Mochamad Riyanto. 2013. Kekerasan di Layar Kaca. Jakarta: PT. Kompas Media Nusantara.

Rukmananda, Naratama. 2004. Menjadi Sutradara Televisi. Jakarta: Grasindo.

Sobur, Alex. 2011. Analisis Teks Media. Bandung: PT Remaja Rosdakarya.

Su'adah. 2005. Sosiologi Keluarga. Malang: UMM Press.

Suparno, Paul, dkk. 2002. Reformasi Pendidikan. Yogyakarta: Kanisius.

Sutisno. 1993. Pedoman Praktis Penulisan Skenario Televisi dan Video. Jakarta. PT. Grasindo.

Vera, Nawiroh. 2010. Pengantar Komunkasi Massa. Jakarta: Renata Pratama Media.

Yunus, Syarifudin. 2010. Jurnalistik Terpaan. Bogor: Ghalia Indonesia. 
JURNAL

Dahlan, M. Alwi. 1980, "Film Dalam Spektrum Tanggung Jawab Komunikasi Massa". Jurnal Penelitian Pembangunan. No 6. Departemen Penerangan.

\section{PUBLIKASI ONLINE}

BBC Indonesia. (2013, April 26). Pengaruh Sinetron Terhadap Kekerasan yang Dilakukan Anak. Retrieved October 12, 2013, from http://www.bbc.co.uk/

Dirhamsyah, M. (2011). Pelanggaran Etika Penyiaran Dalam Sinetron Islam KTP, Studi Analisis Isi Sinetron Islam KTP Episode 185-186 Ditinjau dari Kekerasan Menurut Sunarto. Retrieved Oktober 13, 2013, from Universitas Islam Bandung.

Web site: http://elibrary.unisba.ac.id/files2/skr. 11.80.06071.pdf
Lili, H. (2009). Agresi Anak yang Tinggal dalam Keluarga dengan Kekerasan Rumah Tangga. Retrieved Oktober 11, 2013, from Universitas Gunadarma. Web site: http://www.gunadarma.ac.id/library/a rticles/graduate/psychology/2009/Arti kel_10502140.pdf

Peraturan Komisi Penyiaran Indonesia Nomor 02/P/KPI/03/2012. Standar Program Siaran 2012. Retrieved September 23, 2013, from http://humas.kemsos.go.id/download/ hubungan_antar_lembaga/peraturan_ perundang-undangan/P3SPS_2012.pdf

Rahayu Ginintasasi. (n.d.). Pengertian Komunikasi. Retrieved November 18, 2013, from Universitas Pendidikan Indonesia. Web site: http://file.upi.edu/Direktori/FIP/JUR._ PSIKOLOGI/195009011981032RAHAYU_GININTASASI/Komunikasi.pdf 
Jurnal komunikasi, Volume 9, Nomor 1, Oktober 2014 